\title{
Power Point Game, Motivation, Achievement: The Impact and Students' Perception
}

\section{Gede Budasi}

Dr., Universitas Pendidikan Ganesha, Indonesia, gede.budasi@undiksha.ac.id

\section{Ni Made Ratminingsih}

Dr., Universitas Pendidikan Ganesha, Indonesia, made.ratminingsih@undiksha.ac.id

\section{Ketut Agustini}

Dr., Universitas Pendidikan Ganesha, Indonesia, ketutagustini@undiksha.ac.id

\section{Md. Yudyantara Risadi}

M.Pd., Denpasar Tourism Academy, Indonesia, yudyantara@akpar-denpasar.ac.id

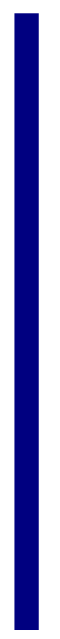

The purpose of this study was to investigate whether there was a significant effect of Power Point game on young learners' learning motivation and English achievement involving learners' perception of it. Based on the characteristics of quantitative research methods, the post-test only control group quasi-experimental design was used to test the effect of the Power Point game and young learners' perception of it. Cluster random sampling was preferred and 84 students participated in this study involving 44 students as the control group and 40 students as the experimental one. Questionnaires and post-test items were used as data collection instruments. To analyze the data obtained from the instruments, ANOVA and MANOVA assisted by SPSS. The findings showed that (1) the students taught by the Power Point game achieved better learning motivation than those taught by visualization through pictures, (2) the students taught by the Power Point game obtained better English achievement than those taught by visualization through pictures, and (3) there was a simultaneous effect of Power Point game on students' learning motivation and English achievement. Thus, these findings also generated students' very good perception of the usage of Power Point Game.

Keywords: English achievement, learning motivation, perception, power point game, young learners, EFL

\section{INTRODUCTION}

In recent years, teaching English to young learners has become important and flourished in many EFL countries. It is believed that an early introduction to English subject

Citation: Budasi, I. G., Ratminingsih, N. M., Agustini, K., \& Risadi, Md. Y. (2020). Power Point Game, Motivation, Achievement: The Impact and Students' Perception. International Journal of Instruction, 13(4), 509-522. https://doi.org/10.29333/iji.2020.13432a 
material can enhance acquisition. It indicates that English taught for young learners can make a better and quicker understanding of a new or target language (Ratminingsih \& Budasi, 2018). However, it is undeniably correct that teaching English for young learners have many problems, one of them is in maximizing learning media (Ratminingsih, 2016). The existence of media in the classroom is one of the key successes in the teaching and learning process. Media can be a mean of grasping their attention since they have a short attention span which indicates that they are easily distracted by surroundings (Ratminingsih \& Mahadewi, 2017). However, attractive and innovative media is rarely used by teachers and lead the students to get the boredom in the classroom (Ratminingsih, 2018; Khoerniawan, et al., 2018). Teachers hardly use innovative teaching media and instructional practices are not characterized by constructivist approaches (Rabgay, 2018). Commonly, teachers use flashcards, sticks, puppets or even text-book only as the media in the classroom, these strategies are not good enough to maintain the attention of young learners as long as needed by the teachers. Teachers need to create or develop a media which can attract young learners' attention and considering their life is surrounded by technology, a teacher should develop a media integrated with technology (Rabu \& Thalib, 2017). Media integrated with the technology used in the classroom is highly recommended because recent education system is rapidly improved and many kinds of technologies have been used in this global era. This mainly aims at improving a better education quality (Agustini \& Wahyuni, 2013). For teachers, media integrated with technology has been able to help them deliver not only cognitive values but also affective and psychomotor values. It makes them easier to teach and assess their students, because they can cover all needed assessment (cognitive, affective, and psychomotor) with it (Agustini \& Tegeh, 2019). For students, it provides a maximum learning experience for them, improves their retention to ensure that each related component supports the achievement of learning objectives, and matches the characteristics of the students (Agustini, 2017). Specifically, for young learners, this kind of technology integrated media brings enjoyment and happiness to them because they are taught by something that is already up to date and familiar with them. Thus, it makes the process within the classroom become a meaningful learning (Shahriarpour \& Kafi, 2014). One of the examples of media integrated with technology is Power Point game. Simply, Power Point game is an educational game created with an application in Microsoft software called Power Point Presentation. This educational game is specially designed to teach young learners new concepts, specific topic, expand their knowledge, and the important thing is young learners are learning by playing (Barbour \& Siko, 2013; Ratminingsih, et al., 2018; Oktaviana, et al., 2017). It is believed that learning using technology in the form of game (playing) was proved to be effectively conducted in primary school classes and there were also improvements in their motivation and activeness in the classroom (Temaja, 2018).

It should be kept in mind that the primary goal of teaching young learners is to help them to gain a better knowledge, understanding, and later on use them in real life. Therefore, it is a necessity to apply a strategy that helps young learners achieve this goal (Negari et al., 2018). Power Point game can help the teacher to achieve it because this 
game inserts audio/music materials as a mean to improve encode, store, and gain a better understanding which make memorizing easier and motivate them to learn in enjoyable situation (Bahrami et al., 2019). Previous studies on incorporating media with technology (Chen, 2017; Risadi, et al., 2017; Ratminingsih, et al., 2018) have proved that it does not only increase students' motivation, but also gain students' better English achievement. Media integrated with technology such as Power Point game has also been agreed to be able to bring new atmosphere of learning, such as more interesting, challenging, and making the students more confident in expressing their opinion in the classroom (Ratminingsih et al., 2018). It means that using Power Point game is a good way of practicing language because it provides a model of what young learners will use the language for real context in the future experience, besides it also provides instant feedback that lets learners know immediately if they have given the wrong answer, which is necessary in the language acquisition process. Learners can play the game again to correct their errors (Al-Elaimat, 2013). Computer game, such as Power Point game can then be introduced as a mean for enabling greater comprehension which lead to better English achievement (Temaja, 2018). Other studies on the use of games have been conducted by several experts. Games have been proved can maintain students' good attitude which leads students to participate more in the classroom and show better understanding of the material (Oktaviana et al., 2017). Specifically, considering the use of games in combination with technology, computer games which becomes the contemporary culture of today's youths is proved to attract young learners and give them the sense of enjoyment thus helping the students, especially young learners' short-term and long-term memories to memorize well the vocabulary taught and at the same time enhancing their achievement (Rabu \& Thalib, 2017). Teaching English through computer game is recommended because it gives significant effect to both learning motivation and achievement and generates students' positive perception on its usage (Ratminingsih et al., 2018). The novelty of this research than other research is on the technology used in this research, Power Point Game which makes a new media to gain the data. In conclusion, teaching English for young learners through Power Point game is effective, meaningful, and low in cost. For this reason, the purpose of this study is aimed at investigating the effect of Power Point game on young learners' learning motivation, English achievement, simultaneously on both of them and students' perception on the effectiveness of its usage after learning by it.

\section{CONTEXT AND LITERATURE REVIEW}

\section{Theoretical Framework}

\section{English achievement}

Learning English achievement is commonly known as the result of students' progress or how success the learner can master the materials of the English subject. Learning achievement is the evaluation of learners after completing certain learning activity (Chen, 2017). English learning achievement can also be defined as a target or level of students' success in learning English in school that are expressed in the form of score obtained from the results of tests on a particular topic and from a particular time. This score can be a sign of the students' improvement (Feng, et al., 2013). This score can 
also define students who have high level of achievement or low level of achievement and cognitive domain is the core of other domains (Kasilingam et al., 2014). It also indicates that students' achievement can describe the level of achievement of students in terms of knowledge, skills and experience of learning formulated by learning objectives from the school curriculum and the results from the test (Riswanto \& Aryani, 2017).

\section{Learning motivation}

Learning motivation is a kind of motivation that refers to the belief within student to guide or lead them to learning goals, induce good learning behaviour for continuous efforts, reinforce cognitive process, and enhance and improve learning outcome (Chen, 2017). Learning motivation is divided into learners' intrinsic learning motivation orientation and extrinsic learning motivation orientation. According to And and Zafar (2016), intrinsic learning motivation refers to a force within the students or it works from within the students like interest, meanwhile, extrinsic motivation refers to environmental energizers like money, This kind of motivation can also be maintained and improved well if the teacher gives the students something new which can grab students' attention and make them curios (Vibulpol, 2016). One of the examples is Power Point Game. Besides, the level of students' motivation can be found out by using ARCS model (Attention, Relevance, Confident, and Satisfaction) developed by John Keller (Rahardjanto et al., 2019).

\section{Power point game}

Power Point game is a game made by an application in Microsoft software named Power Point Presentation and this game can give a good design for students to make them more focus on learning process. The strengths of this game are among others, it provides an opportunity to model an activity, it can be fun to play, it is easy to create or edit, and it does not require an internet connection (Barbour \& Siko, 2013). According to Polly (as cited in Oktaviani et al., 2017), Power Point Game has some criteria, namely, 1) students' interest can be improved well 2) it has values of learning income, 3) the component of game is available, 4) creativity of the game maker can be involved. It is essential for providing opportunities for young learners to learn to operate in an information age. Students are also capable to play the game with good instruction given by the Power Point because the variety of design and animation could stimulate students' interest and learn well in the classroom (Ali, et al., 2013). Thus, it can be inferred that Power Point game is a simple, yet fruitful media to capture students' attention and interest to study.

\section{Perception}

Perception is regarded as individual interpretation of something which is affected by past experiences, current understanding, present situation, and information (Nikian et al., 2013). In this present study, the interpretation is brought after the students have past experiences and current understanding on Power Point game. Other researchers believe that perception deals with the human senses that generate signals from the environment through sight, hearing, touch, smell and taste and then, able to decide a conclusion based on them. Thus, students in this recent study can decide any conclusion about the usage of Power Point game based on what they see, hear, touch, smell, and taste (Knuuttila and 
Karkkainen, 2008). A person's awareness and acceptance of the stimuli in this study, Power Point game play an important role in the perception process (Pickens, 2005). It indicates a person interprets the stimuli into something meaningful to him or her based on prior experiences.

\section{Young learners}

The expression of young learners are applied to children from the age of three to twelve (Bland, 2015). Young learners in this study was the $4^{\text {th }}$ grade elementary school students and they are considered as young learners since their age is around 9-10 years. They have some special characteristics to be considered by the teacher if they are learning a subject matter, a quite short attention span and easy to get bored are the common special characteristics of young learners (Juhana, 2014). Ratminingsih (2016) suggests that teaching young leaners can be done successfully if the teacher uses a media with good visual aids, colourful objects, and combined with a game that attracts them. It signifies that using innovative media as a means of teaching subject matter can be one of the solutions to maximize teaching and learning process (Ratminingsih \& Budasi, 2018.

\section{METHOD}

The current study investigated the effect of Power Point game (independent variable) on learning motivation and English achievement (dependent variables). Hence, quasi experiment that applied post-test only control group design was used to assess the effect of the independent variable on dependent variables. Besides, this method was also used because of limited time and sources in conducting the research. The study design involved two classes of the students assigned to experimental and control groups. In the experimental group, English subject was taught through a media called Power Point game and in the control group, it was taught by using visualization through pictures considered as conventional teaching.

\section{Population and Sample}

The population of this study was 352 of fourth grade elementary school students in Denpasar, particularly in South Denpasar district. Random sampling technique was taken to determine two intact groups as the samples of the study. It was found that 40 students in SD Negeri 2 Sesetan became the experimental group and 44 students in SD Negeri 6 Sesetan became the control group.

\section{Data Collection Procedures}

This current study used two questionnaires and three post-tests as the instruments to collect the data. The first questionnaire was Learning Motivation through Game Playing Questionnaire (LMGP-Q). The questionnaire was adapted from Keller's ARCS model with 30 items. The second questionnaire was students' perception on the use of Power Point game with 30 items. The scale used in these questionnaires is a Likert type 5 scale. The post-tests were made based on the consideration of topics (Numbers, Electronic Appliances, and Things around the Classroom) with 40 items of each topic.

The instruments were examined by two expert judges to find out the content validity calculated by using Gregory Formula. The content validity of LMGP-Q was 1.00, while, the questionnaire of students' perception was 0.90 . For post-tests, the content validity of 
topic number, electronic appliances, and things around the classroom, respectively 0.95 , 0925, and 0.975. Furthermore, they were tried out (involving students beyond samples) to measure the empirical validity and reliability. For LMGP-Q, there was no invalid item with reliability value 0.89 . Meanwhile, for the questionnaire of students' perception, there were 24 valid items with reliability value 0.87 . For post-tests, under the topic "Number" there were 33 valid items and the reliability value was 0.91 , "Electronic Appliances", there were 35 valid items and the reliability value was 0,92. Lastly, "Things around The Classroom", 34 items were valid and the reliability value was 0.89 . Hence, all instruments had very high reliability and were proceeded to be used for giving treatment.

For the analysis of the obtained data, descriptive and inferential analysis were used. In descriptive analysis, it was used to find out the central tendency, such as mean, maximum, and minimum score. Further, the inferential analysis, ANOVA and MANOVA were used to find out whether there is a significant effect of Power Point game on learning motivation, English achievement, and simultaneously on both of them. Before conducting inferential analysis, normality, homogeneity variance test, and homogeneity of variance/covariance matrix test were applied as the pre-requisite analysis. Those data analysis was assisted by SPSS 22.0 with a significance level of $5 \%$ (0.05). Meanwhile, the obtained data from the questionnaire of the students' perception on the usage of Power Point was analyzed by calculating its percentage.

\section{FINDINGS}

The result of descriptive analysis in experimental and control group is shown in the Table 1.

Table 1

The Descriptive Analysis

\begin{tabular}{lllll}
\hline & A1Y1 & A2Y1 & A1Y2 & A2Y2 \\
\hline Mean Score & 116.63 & 94.66 & 76.08 & 57.41 \\
Maximum Score & 129.00 & 104.00 & 84.00 & 67.00 \\
Minimum Score & 108.00 & 86.00 & 70.00 & 48.00 \\
\hline
\end{tabular}

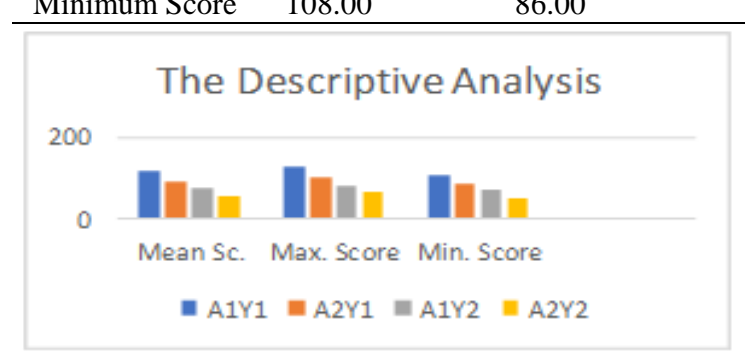

Figure 1

The Data of Descriptive Analysis

To determine the categorization of learning motivation and English achievement's mean score, the interval is given in Table 2 and Table 3. 
Table 2

The Categorization of Mean Score of Students' Learning Motivation

\begin{tabular}{lll}
\hline No & Interval & Categorization \\
\hline 1 & $120.00 \leq \mathrm{M} \leq 150.00$ & Very High \\
2 & $100.00 \leq \mathrm{M}<120.00$ & High \\
3 & $80.00 \leq \mathrm{M}<100.00$ & Average \\
4 & $60.00 \leq \mathrm{M}<80.00$ & Low \\
5 & $30.00 \leq \mathrm{M}<60.00$ & Very Low \\
\hline
\end{tabular}

Table 3

The Categorization of Mean Score of Students' English Achievement

\begin{tabular}{lll}
\hline No & Interval & Categorization \\
\hline 1 & $75 \leq \mathrm{M} \leq 100$ & Very High \\
2 & $58.33 \leq \mathrm{M}<75$ & High \\
3 & $41.67 \leq \mathrm{M}<58.33$ & Average \\
4 & $25 \leq \mathrm{M}<41.67$ & Low \\
5 & $0 \leq \mathrm{M}<25$ & Very Low \\
\hline
\end{tabular}

Taking into account table 2, the mean score of students' learning motivation in experimental group is categorized in interval high level of learning motivation, while the mean score of students in control group is categorized in interval average level of learning motivation. It showed that students taught by Power Point game had better learning motivation than those taught by using visualization through pictures. Furthermore, considering the interval given in table 3, the mean score of students' English achievement in experimental group is categorized in interval very high level of English achievement and mean score of students in control group is categorized in interval average. It also signified that students taught by using Power Point game obtained better achievement than students taught by visualization through pictures.

Further, investigating whether there is significant effect of Power Point game on learning motivation, English achievement, and simultaneous effect, inferential analysis ANOVA and MANOVA were conducted. Before conducting the inferential analysis, pre-requisite tests such as normality, homogeneity of variance, and homogeneity of variance /covariance test were administered first. Those results are shown in the following table 4,5 , and 6 .

Table 4

Tests of Normality

\begin{tabular}{lccllll}
\hline \multicolumn{3}{c}{ Kolmogorov-Smirnova } & \multicolumn{4}{c}{ Shapiro-Wilk } \\
\hline & Statistic df & Sig. & Statistic & df & Sig. \\
\hline Achievement A1 & .078 & 40 & $.200^{*}$ & .991 & 40 & .985 \\
Achievement A2 & .083 & 40 & $.200^{*}$ & .982 & 40 & .765 \\
Motivation A1 & .126 & 40 & .110 & .962 & 40 & .192 \\
Motivation A2 & .100 & 40 & $.200^{*}$ & .975 & 40 & .508 \\
\hline
\end{tabular}

Table 5

Homogeneity of Variance Levene's Test of Equality of Error Variances

\begin{tabular}{lllll}
\hline & F & df1 & df2 & Sig. \\
\hline Motivation & .008 & 1 & 82 & .930 \\
Achievement & 3.189 & 1 & 82 & .078 \\
\hline
\end{tabular}


Table 6

The Result of Homogeneity of Variance/Covariance Matrix Test

Box's Test of Equality of Covariance Matrices

\begin{tabular}{|c|c|}
\hline \multicolumn{2}{|c|}{ Box's M 4.862} \\
\hline $\mathrm{F}$ & 1.578 \\
\hline df1 & 3 \\
\hline $\mathrm{df} 2$ & 1727601.816 \\
\hline Sig. & 192 \\
\hline
\end{tabular}

Based on the above tables, it is inferred that ANOVA and MANOVA analyses could be conducted since the significant value of all pre-requisite tests were higher than a significance level of 5\% (0.05). The results of ANOVA and MANOVA analysis assisted by SPSS 22.0 is presented in table 7, 8 and 9 .

Table 7

The Result of Hypothesis testing I Using One-Way ANOVA

Dependent Variable: Motivation

\begin{tabular}{lcllll}
\hline Source & Type III Sum of Squares & df & Mean Square & F & Sig. \\
\hline Corrected Model & $10109.548 \mathrm{a}$ & 1 & 10109.548 & 589.075 .000 & \\
\hline Intercept & 935334.548 & 1 & 935334.548 & 54501.200 & .000 \\
\hline Code & 10109.548 & 1 & 10109.548 & 589.075 .000 & \\
\hline Error & 1407.261 & 82 & 17.162 & & \\
\hline Total & 939718.000 & 84 & & & \\
\hline Corrected Total & 11516.810 & 83 & & & \\
\hline a. R Squared $=.878$ (Adjusted R Squared $=.876)$ & & & & \\
\hline
\end{tabular}

Based on table 7 , the ANOVA analysis shows that the significant value of learning motivation was less than $0.05(5 \%)$. It means there is a significant effect of Power Point game on students' learning motivation. It is also proved that there was Effect Size of Power Point game on students' learning motivation in the amount of $87.6 \%$ (Adjusted $\mathrm{R}$ Squared $=.876)$.

Table 8

The Result of Hypothesis Testing II using one-way ANOVA

\begin{tabular}{lclllll}
\hline Dependent Variable: & Achievement & & & & \\
\hline Source & Type III Sum of Squares df & \multicolumn{2}{l}{ Mean Square } & F & \multicolumn{2}{l}{ Sig. } \\
\hline Corrected Model & $7300.148 \mathrm{a}$ & 1 & 7300.148 & 476.825 .000 & \\
\hline Intercept & 373329.577 & 1 & 373329.577 & 24384.856 & .000 \\
\hline Code & 7300.148 & 1 & 7300.148 & 476.825 .000 & \\
\hline Error & 1255.411 & 82 & 15.310 & & & \\
\hline Total & 377767.000 & 84 & & & & \\
\hline Corrected Total & 8555.560 & 83 & & & \\
\hline
\end{tabular}

a. R Squared $=.853$ (Adjusted R Squared $=.851$ )

The result of whether there is significant effect of Power Point on English achievement is presented in table 8 . From the table, it is concluded that there is a significant effect of Power Point game on students' English achievement because the significant value of 
English achievement was lower than 0.05 It is also proved that there was Effect Size of Power Point game on students' English achievement in the amount of 85.1\% (Adjusted $\mathrm{R}$ Squared $=.851)$.

Table 9

The Result of Hypothesis Testing III using MANOVA

Multivariate Tests

\begin{tabular}{|c|c|c|c|c|c|c|}
\hline \multicolumn{2}{|l|}{ Effect } & \multirow{2}{*}{$\begin{array}{l}\text { Value } \\
.999 \\
\end{array}$} & \multirow{2}{*}{$\begin{array}{l}\mathrm{F} \\
39227.968 \mathrm{~b}\end{array}$} & \multirow{2}{*}{$\begin{array}{l}\text { Hypothesis df } \\
2.000\end{array}$} & \multirow{2}{*}{$\begin{array}{l}\text { Error df } \\
81.000\end{array}$} & \multirow{2}{*}{$\begin{array}{l}\text { Sig. } \\
.000\end{array}$} \\
\hline Intercept & Pillai's Trace & & & & & \\
\hline & Wilks' Lambda & .001 & $39227.968 b$ & 2.000 & 81.000 & .000 \\
\hline \multicolumn{2}{|c|}{ Hotelling's Trace } & 968.592 & $39227.968 b$ & 2.000 & 81.00 & .000 \\
\hline \multicolumn{2}{|c|}{ Roy's Largest Root } & 968.592 & $39227.968 b$ & 2.000 & 81.000 & .000 \\
\hline \multirow[t]{4}{*}{ PPT Game } & Pillai's Trace & .929 & $530.315 b$ & 2.000 & 81.000 & .000 \\
\hline & Wilks' Lambda & .071 & $530.315 b$ & 2.000 & 81.000 & .000 \\
\hline & Hotelling's Trace & 13.094 & $530.315 b$ & 2.000 & 81.000 & .000 \\
\hline & Roy's Largest Root & 13.094 & $530.315 b$ & 2.000 & 81.000 & .000 \\
\hline
\end{tabular}

Last but not least, the result of MANOVA analysis to find out whether there is simultaneous effect of Power Point game on students' learning motivation and English achievement is presented in table 9. From table 9, it was found that the significant value of the effect of Power Point game was lower than $0.05(5 \%)$. Thus, it is proved that there is a simultaneous effect of Power Point game on students' learning motivation and English achievement.

The description of students' perception on the effectiveness of the usage of Power Point game is also presented in table 10. This was intended to find out how well the students increase their knowledge after being taught by Power Point game as a media for teaching them in English subject (Experimental Group Only). The criteria of the effectiveness is also presented in table 11 (Ratminingsih et al., 2018).

Table 10

Students' Perception on the Effectiveness of Power Point game

\begin{tabular}{lll}
\hline Aspect Evaluated & Score Achieved & Percentage \\
\hline Increase of vocabulary knowledge & 1450 & 90.6 \\
Increase of explaining the meaning of words & 1428 & 89.3 \\
Increase of skill in using words in short sentences/paragraph & 1490 & 93.1 \\
N=40 Items per aspect=8 & & \\
Option (Likerts' scale)= 5 Total Score= 1600 & \\
Score= Total score/maximum score achieved x 100\% & \\
\hline
\end{tabular}

Table 11

Criteria of Effectiveness

\begin{tabular}{lll}
\hline No & Score & Effectiveness \\
\hline 1 & $85-100$ & Very Good \\
2 & $70-84$ & Good \\
3 & $55-69$ & Moderate \\
4 & $40-54$ & Less Good \\
5 & $0-39$ & Not Good \\
\hline
\end{tabular}


The questionnaire of students' perception on the effectiveness of the usage of Power Point game showed that students in experimental group achieved score 1450 (percentage $90.6 \%$ ) in aspect increase of vocabulary knowledge, achieved score 1428 (percentage $89.3 \%$ ), and in aspect of increase of skill in using words in short sentences/paragraph achieved score 1490 (percentage 93.1\%). It can be implied that students taught by Power Point game had very good perception on the effectiveness of its usage in classroom.

\section{DISCUSSION AND CONCLUSION}

The aim of this study was four folds. Firstly, it is sought to investigate the effect of Power Point game on young learners' learning motivation. The result of descriptive analysis and one-way ANOVA shows that young learners taught by Power Point game significantly performed better than control group regarding to higher mean score and since the significant value in one-way ANOVA was lower than 0.05 indicated there was significant effect of Power Point game on learning motivation of students. This finding is supported by a theory from Mahmmoud and Tanni (2014) who stated that educational computer game or game-based learning is a kind of activities in learning subject used as motivating power for learners. It indicates that when students are given games in learning a subject matter, they are more likely motivated, engaged, and participated in learning. Moreover, Chen (2017) supported by Alizadeh (2016) conveyed that game based learning instruction could enhance students' learning motivation. It means that using game especially digital game can make the students more motivate in learning as fast as the game is given to them. The learning motivation of students is induced differently in games, it implies students with different level motivation can learn well together when digital game is applied in the classroom. This statement is also following Ratminingsih et al., (2018) who argued that in the form of non-cognitive factor, Power Point game brings relaxation, joyfulness, and motivation in learning. In this context, it is proved that Power Point game used for the experimental group gave so much happiness and joyfulness to the students. Oktaviana et al. (2016) also supported this finding, they revealed that implementing Power Point game gave positive effect to the students' motivation. The existence of technology in the classroom is beneficial for learning as a result of being a motivational tool for learners. It can be concluded that the students felt enjoy and fun in the learning process and it increased their motivation in learning. Hence, the use of Power Point game gave a significant effect on students' learning motivation

Secondly, it also intended to investigate the effect of Power Point game on young learners' English achievement. Based on the finding, it was proved that young learners in experimental group achieved better than the control group seen from the mean score which was higher and there was a significant effect of Power Point game on young learners' English achievement since the significant value of one-way ANOVA was lower than 0.05. This finding is supported by Al-Elaimat (2013), that there are significant statistical differences on students achievement in English attributed to learn by computer games and learn traditionally. Rabu and Thalib (2017) also added that in the context of young students' learning, especially for English as a second language 
(ESL) subject, digital game activity is the appropriate application for strengthening and enrichment exercises. It signals that digital game such as Power Point game can give various exercises to enrich students' knowledge and improve their achievement in the end of learning process. Power Point game can improve students' understanding and reinforce student's long-term memory on a subject being taught. The mostly cited reasons why Power Point game affected the young learners' achievement was because of the satisfaction derived when they accomplished a challenge in Power Point game in students' classroom. Power Point game features such as, background music, animations, direct feedback, creativity, relaxation, gave satisfaction which leads them to create the knowledge and achieve better score in English subject (Vitianingsih, 2106).

Thirdly, the aim of this study was also to investigate whether theres is a simultaneous effect of Power Point game on students' learning motivation and English achievement. Based on the analysis of MANOVA, it can be concluded that there was a simultaneous effect of Power Point game on learning motivation and English achievement of the students which could be seen in the significant value that was lower than 0.05. As stated by Rabu and Thalib (2017) and supported by Chen (2017), computer game such as Power Point game had features which provide the opportunities for students to engage and participate more in learning English subject material. The challenges, controls, interactivity, and feedbacks bring interest, happiness, enjoyment, and joyfulness of learning subject material. These features stimulated students' attention in subject, relevance of learning with real world, confidence in expressing, and satisfaction in result. In the other words, it fostered and maintained the aspects of students' learning motivation thus students will have better motivation in learning. By having better motivation, students engaged and participate more in learning English subject material. According to Al-Elaimat (2013) when their learning motivation is improved, at the same time they gained higher achievement. Therefore, the finding of this study is following Risadi, et al. (2017) that Power Point game gave significant effect on students' learning motivation and English achievement. As the current study revealed, this process was proved to be effective in developing the students' learning motivation, enhancing their English achievement, and gave effect both of them simultaneously.

Fourthly, this study also aimed at investigating students' perception on the effectiveness of Power Point usage after learning through it. The result of students' questionnaire shows that they have very good perception on the usage of Power Point game. They assure that after learning English by mean of Power Point game, their vocabulary mastery is increased. This statement is also supported by Temaja (2018) who argued that vocabulary is one of sub-skills of language that is involved in digital game, such as Power Point game. It indicates that while students are playing the game, they are also learning vocabulary unconciusly resulting to the increase of vocabulary mastery/knowledge of them. He adds that students also increase the skill of using words in short sentence/paragraph since Power Point game provides a model of what young learners will use the language for real context in the future experience. It is also in line with Farrokh and Sharifi (2019) who supplemented that an effective teaching media, in this study Power Point game can foster the vocabulary mastery of the students because it engages students to bring their imagination up to guess the unknown or unfamiliar words 
and make learning vocabulary motivate and interest, thus students are involved more in vocabulary learning process. The finding of current study corresponds with some previous studies (Purnami et al., 2017; Asnadi et al., 2018; Ratminingsih et al., 2018), those previous studies proved that students' perception was positive on the implementation of innovative media (Power Point Game) toward their learning motivation as well as concerning on their English achievement.

Eventually, it can be concluded that Power Point Game is powerful and beneficial media to give an effect toward the students' learning motivation and English achievement. The students treated with Power Point game showed better learning motivation than those treated with conventional media (visualization through pictures), there is a significant difference in terms of achievement's mean score of students in experimental group and control group. The experimental group performed better on students' English achievement than those in control group. There is also a simultaneous effect on both of them. Moreover, it leads to the students to give their very good perception on the effectiveness of the use of Power Point game. Consequently, it is strongly recommended that teachers can maximize the use of Power Point Game as an alternative teaching and learning strategy to be implemented in teaching young learners. For the students, it is suggested to continuously learn with Power Point Game to maintain their learning motivation, so that they can also improve their English achievement.

\section{REFERENCES}

Agustini, K., Wahyuni, D. S. (2013). Pengaruh penggunaan simulasi binary tree berbasis CAI terhadap motivasi dan hasil belajar matematika diskrit mahasiswa jurusan PTI Undiksha. JPI (Jurnal Pendidikan Indonesia), 2(1), 162-172.

Agustini, K. (2017). The adaptive E-learning system design: Student learning style trend analysis. In 2nd International Conference on Innovative Research Across Disciplines (ICIRAD 2017). Atlantis Press.

Agustini, K., \& Tegeh, I. M. (2019). Learning style tendency analysis for vocational students. Journal of Physics: Conference Series, 1165(1), 012022.

Al-Elaimat, A. R. (2013). The effect of using computer games on lower basic stage students' achievement in English at Al-Salt schools. Int Edu Studies, 6(2), 160-171.

Ali, G., Haolader, F. A., \& Muhammad, K. (2013). The role of ICT to make teachinglearning effective in higher institutions of learning in Uganda. International Journal of Innovative Research in Science, Engineering and Technology, 2(8), 4061-4073.

Alizadeh, M. (2016). The impact of motivation on English language learning. International Journal of Research in English Education, 1(1), 11-15.

And, S. L., \& Zafar, S. (2016). Motivation in second language learning - A retrospect. International Interdisciplinary Research Journal, 4(1), 7-13.

Asnadi., I., Ratminingsih, N. M., \& Myartawan, I. (2018). Primary teachers' and students' perception on the use of ICT-based interactive game in English language teaching. Jurnal Pendidikan Indonesia, 7(1), 10-20. 
Bahrami, Z. N., Izadpanah, S., \& Bijani, M. (2019). The impact of musical mnemonic on vocabulary recalling of Iranian young learners. Int J of Instruction, 12(1), 977-994.

Barbour, M. K., \& Siko, J. P. (2013). Game design and homemade power point games: An examination of the justifications and a review of the research. Journal of Educational Multimedia and Hypermedia, 22(1), 81-108.

Bland, J. (2015). Teaching English to young learners: Critical issues in language teaching with 3-12 year olds. Britain: British Library Cataloguing-in-Publication.

Chen, Y. C. (2017). Empirical study on the effect of digital game-based instruction on students' learning motivation and achievement. EURASIA Journal of Mathematics Science and Technology Education, 13(7), 3177-3178.

Farrokh, P., \& Sharifi, F. (2019). On the impact of determination and compensation strategies on language learners' vocabulary development. Int J of Ins, 12(3), 1-14.

Feng, Y. H., Fan, J. Y., \& Yang, H. Z. (2013). The relationship of learning motivation and achievement in EFL: Gender as an intermediated variable. Edu Res Int, 2(2), 50-58.

Juhana. (2014). Teaching english to young learners: Some points to be considered. Asian Journal of Education and e-Learning, 2(1), 43-46.

Kasilingam, G., Ramalingam, M., \& Chinnavan, E. (2014). Assessment of learning domains to improve student's learning in higher education. Journal of Young Pharmacists, 6(1), 27-33.

Khoerniawan, R. W., Putrama, I. M., Agustini, K. (2018). Game edukasi penjelajah berbasis virtual reality. Kumpulan Artikel Mahasiswa Pendi. Teknik Informatika, 7(1).

Knuuttila, S., \& Karkkainen, P. (2008). Theories of perception in medieval and early modern philosophy. Finland: Springer

Mahmoud, A. A., \& Tanni, Z. A. (2014). Using games to promote students' motivation towards learning English. Al-Quds Open University Journal for Educational \& Psychological Research \& Studies, 2(5), 13-33.

Negari, G. M., Azizi, A., \& Arani, D. K. (2018). Investigating the effectiveness of audio input enhancement on EFL. International Journal of Instruction, 11(1), 123-138.

Nikian, S., Nor, F. M., \& Aziz, M. A. (2013). Malaysian teacher's perception of applying technology in the classroom. Int Educational Conference, 103(2013), 621-627.

Oktaviana, S., Santoso, B., \& Hiltrimartin, C. (2017). Penggunaan Power Point Game pada pembelajaran lingkaran di kelas VIII SMP negeri 1 Tanjung Raya. Jurnal Pendidikan Matematika, 11(1), 29-42.

Pickens, J. (2005). Attitudes and perceptions. In N. Borkowski (Ed.), Organizational behavior in helath care (pp. 43-76). Sudbury, Mass. : Jones and Bartlett Publishers.

Purnami, L. P. Y. I., Ratminingsih, N. M., \& Suputra, P. E. D. (2017). Teachers' and students' perception on the use of ICT based interactive game in 4th grade of elementary 
school in Sukasada district in academic year 2016/2017. Jurnal Pendidikan Bahasa Inggris Undiksha, 4(2), 101-110.

Rabu, S. A., \& Talib, Z. (2017). The effects of digital game-based learning on primary school students' English vocabulary. Innovative Teaching and Learning J., 1(1), 61-74.

Ragbay, T. (2018). The effect of using cooperative learning method on tenth grade. International Journal of Instruction, 11(2), 265-280.

Rahardjanto, A., Husamah, \& Fauzi, A. (2019). Hybrid-PjBL: Learning outcomes, creative thinking skills, and learning motivation of pre-service teacher. International Journal of Instruction, 12(2), 179-192.

Ratminingsih, N. M. (2016). Effectivitas media audio pembelajaran berbahasa inggris berbasis lagu kreasi di kelas limasekolah dasar. J. Pendidikan Indonesia, 5(1), 714-724.

Ratminingsih, N. M., \& Mahadewi, L. P. (2017). IBM kelompok guru bahasa inggris sekolah dasar di kecamatan Sukasada. Majalah Apl. Ipteks NGAYAH, 8(1), 127-143.

Ratminingsih, N. M. (2018). Implementasi board games dan pengaruhnya terhadap hasil belajar Bahasa Inggris. Jurnal Pendidikan Indonesia, 24(1), 19-28.

Ratminingsih, N. M., \& Budasi, I. G. (2018). Local culture-based picture storybooks for teaching English for young learners. SHS Web of Conferences, 42, 00016. doi: 10.1051/shsconf/20184200016.

Ratminingsih, N. M., Mahadewi, L. P., \& Divayana, D. H. (2018). ICT-based interactive game in TEYL: Teachers' perception, students' motivation, and achievement. International J. of Emerging Technologies in Learning, 13(09), 190-203.

Risadi, M. Y., \& Ratminingsih, N. M. (2017). The Effect of The Use of ICT-Based Interactive Game on Achievement Motivation and English Achievement of 4th Grade Elementary School Students in Cluster V of Sukasada District in Academic Year 2016/2017. Jurnal Pendidikan Bahasa Inggris undiksha, 4(2).

Riswanto, A., \& Aryani, S. (2017). Learning motivation and student achievement: Description analysis and relationships both. The I $J$ of Counseling and Edu, 2(1), 42-47.

Shahriarpour, N., \& Kafi, Z. (2014). The effect of playing digital games on Iranian intermediate EFL learners' motivation toward learning English vocabularies. Social and Behavioral Sciences 98, 2(1), 1738 - 1743.

Temaja, I. B. (2017). E-matching game in teaching English for young learners. International Journal of Social Sciences, 3(1), 67 - 79.

Vibuphol, J. (2016). Students' motivation and learning and teachers' motivational strategies in english classrooms in Thailand. English Language Teaching, 9(4), 64-75.

Vitianingsih, A. V. (2016). Game edukasi sebagai media pembelajaran pendidikan anak usia dini. Jurnal INFORM, l(1), 25-32. 